IZA DP No. 6566

A Theory of Expert Leadership

Amanda H. Goodall

May 2012 


\title{
A Theory of Expert Leadership
}

\author{
Amanda H. Goodall \\ IZA and Cass Business School
}

\section{Discussion Paper No. 6566 \\ May 2012}

\author{
IZA \\ P.O. Box 7240 \\ 53072 Bonn \\ Germany \\ Phone: +49-228-3894-0 \\ Fax: +49-228-3894-180 \\ E-mail: iza@iza.org
}

\begin{abstract}
Any opinions expressed here are those of the author(s) and not those of IZA. Research published in this series may include views on policy, but the institute itself takes no institutional policy positions.

The Institute for the Study of Labor (IZA) in Bonn is a local and virtual international research center and a place of communication between science, politics and business. IZA is an independent nonprofit organization supported by Deutsche Post Foundation. The center is associated with the University of Bonn and offers a stimulating research environment through its international network, workshops and conferences, data service, project support, research visits and doctoral program. IZA engages in (i) original and internationally competitive research in all fields of labor economics, (ii) development of policy concepts, and (iii) dissemination of research results and concepts to the interested public.
\end{abstract}

IZA Discussion Papers often represent preliminary work and are circulated to encourage discussion. Citation of such a paper should account for its provisional character. A revised version may be available directly from the author. 


\section{ABSTRACT}

\section{A Theory of Expert Leadership ${ }^{*}$}

How much knowledge should leaders have of their organization's core business? This is an important question but not one that has been addressed in the management literature. In a new 'theory of expert leadership' (TEL), this paper blends conceptual work with recent empirical evidence. It suggests that organizations perform more effectively when led by individuals who have a deep understanding of the core business of their organization. Being a capable general manager is not sufficient. Expert leaders are those with (1) inherent knowledge, acquired through technical expertise combined with high ability in the corebusiness activity; (2) industry experience, which stems from time and practice within the corebusiness industry; and (3) leadership capabilities, which include management skills and a leader's innate characteristics. This paper criticizes the rise of the professional manager and generalist CEO. It argues that expert leaders improve organizational performance through knowledge-based strategy, by acting as a standard bearer, by creating the right environment for core workers, and, finally, by adopting the long view. The paper concludes by identifying the potential boundaries of TEL.

JEL Classification: J24, M12, M51

Keywords: expert leaders, CEOs, inherent knowledge, core business, organizational performance

Corresponding author:

Amanda H. Goodall

IZA

P.O. Box 7240

D-53072 Bonn

Germany

E-mail: goodall@iza.org

\footnotetext{
For valuable discussions, I am particularly grateful to Chris Edger, Andrew Oswald and Ganna Pogrebna. Thanks also to James Oswald, Malcolm Oswald and three anonymous referees from the Academy of Management for their helpful suggestions.
} 


\section{INTRODUCTION}

One of the unanswered questions about leaders in real-world settings is how much core-business knowledge they should have to be able to perform effectively. How important is it that the Managing Director of McKinsey's was himself or herself an outstanding consultant? Do high-tech firms or scientific institutions perform better when they are led by technical experts? Do German automobile companies perform so well because engineers are on the shop floor and in the boardroom? An equivalent much-discussed issue in medicine is whether MDs should replace professional managers in key leadership positions in hospitals. More common still is the debate between sports enthusiasts about whether the coach of their beloved basketball team or soccer club should have been a great player.

This issue is discussed in hiring panels around the world, yet it has not been systematically examined in the management literature. This paper combines theoretical ideas with new empirical work in an attempt to contribute toward a 'theory of expert leadership $^{1}$.

The key idea in this paper is that organizations perform most effectively when they are led by individuals who have inherent knowledge of the core business activity. This is germane because there is recent evidence that major firms have moved away from hiring CEOs with technical expertise, towards instead the selection of leaders who are generalists (Frydman, 2007; Bertrand, 2009). Incorporated into the theory of expert leadership (hereafter TEL) is the suggestion that in the choice of leaders the pendulum may have swung too far from core business functions towards management functions. I argue, first, that in most circumstances the underlying business of an organization should determine the choice of managerial candidates; and, second, that the extent to which an individual has inherent knowledge of and high ability in the core activity should help to determine the leader.

\footnotetext{
${ }^{1}$ The ideas in this paper were first suggested in Goodall 2006, 2007 (PhD thesis) and 2009a,b.
} 
Whether an organization is public or not-for-profit or private is deemed here to be less important. Instead, it is the core business knowledge that matters and that differentiates leaders from general managers. This contrasts with a focus in the literature on 'what leaders do’' (Kotter, 1990), and instead examines what their organizations do.

The paper's arguments in support of TEL are drawn from recent empirical studies and literatures from a number of fields -- in particular the creativity and expertise literature, upper echelons theory, research on CEO origin, management science, and economics. The suggestion that leader characteristics should closely align with core business activity is empirically motivated. Empirical studies are reviewed in the next section of the paper. In the section that follows, a model for TEL is presented. Here the key components of the theory are explored and testable propositions raised. The processes through which expert leaders might affect organizational performance -- potential transfer mechanisms -- are then discussed. In the penultimate section of the paper I examine the potential boundaries of TEL; and finally I touch upon the negative characteristics that may be associated with expert leaders.

\section{EMPIRICAL SUPPORT FOR EXPERT LEADERSHIP}

The suggestion that leaders and followers should share technical expertise has mostly been studied within the context of creativity. Mumford, Scott, Gaddis, \& Strange (2002) summarize these findings and report that the evidence is clear: to lead creative individuals requires both 'technical and creative problem-solving skills' since, as the authors suggest, 'they provide a basis for structuring an inherently ill-defined task and because they provide the credibility needed to exercise influence' (2002, p. 712). The earliest study reported is by Andrews and Farris (1967) who examine scientists' productivity. They found that the best 
predictor of a researcher's creative performance was the leader's level of technical ability -in other words, how good a scientist the leader was -- as compared with other factors including motivating others, maintaining group relationships, and the amount of autonomy granted to staff. These results were replicated in a similar study by Barnowe (1975).

Mumford et al. (2002) turn to the literature to answer the question: why does a leader's technical expertise matter to the performance of other creatives? (See Thamin \& Gemmill 1974; Basadur, Runco, \& Vega 2000; McAuley, Duberley \& Cohen, 2000; Mumford, Marks, Connelly, Zaccaro \& Reiter-Palmon, 2000). They report, first, that the evaluation of creative people and their ideas can only be done by individuals who share their competencies; in short, it takes one to know one (or competently assess one). Second, leaders who share the same creative and technical perspective and motivation as their followers can communicate more clearly; finally, in relation to performance, they can better articulate the needs and goals of the organization.

More recently in a similar setting, the research question 'who should lead research universities?' was examined in a number of studies (Goodall, 2006; 2009 a,b). The first (2006) was a cross-section that correlated a leader's level of scholarship (measured through their lifetime citations) with the position of their university in a global ranking of onehundred. The relationship, which was statistically significant at the $\mathrm{p}<0.001$ level, showed that universities positioned higher in the league table were more likely to be led by outstanding scholars compared with those lower down the table (see Goodall 2006). A second study of research universities, using regression equations with longitudinal data and lags, showed that university leaders who were better scholars were associated with better university performance a number of years later (see Goodall 2009a,b). These findings support earlier work (e.g. Andrews \& Farris, 1967; Barnowe, 1975), albeit the unit of observation is a step from research teams to research organizations. 
A further study examines the same question in data from another high-skill setting (Goodall, Kahn \& Oswald, 2011). The authors found that a strong predictor of a leader's success in year $\mathrm{T}$ was that person's level of attainment, in the underlying activity, in approximately year T-20; the paper documents a correlation between brilliance as a basketball player and the (much later) winning percentage and playoff success of that person as a basketball coach. The result strengthens for coaches who were former All-Stars (i.e. the most outstanding players).

In another cross-section study, this time using US hospital data (Goodall, 2011), CEOs were classified into two types: those who were medically trained (MDs) on the one hand, and CEOs who were professional managers on the other. The ranked position of each hospital was then correlated with the CEOs' characteristics. In the statistical analyses, the regression equations revealed that the presence of a physician-CEO was positively associated with an extra 8 to 9 hospital quality points on an 80-point scale (at the $p<0.001$ level); in short, hospital quality scores were approximately $25 \%$ higher in physician-run hospitals than in the average hospital.

Finally, this pattern has been replicated in a recent study that uses almost six decades of field data from the highly competitive industry of Formula 1 World Constructors' Championship (Goodall \& Pogrebna, 2012). In Formula 1 racing, each constructor team competes for winning the Championship by entering two cars into multiple consecutive races every year. The results show that the most successful team leaders in Formula 1 motor racing are more likely to have started their careers as drivers -- as compared with other kinds of leaders who were principally managers, mechanics, or engineers (with degrees). The result is strengthened the more years the team principal spent in competitive driving. Thus, once again, the results suggest that leaders with inherent knowledge of the core-business activity, 
combined with extensive industry experience, are associated with better organizational outcomes.

The abovementioned findings motivate the proposed theory of expert leadership outlined in this paper. It is important to note that these studies have focused on knowledgeintensive settings. This is partially because measurement of both performance outputs and CEO characteristics are somewhat easier in these fields. The relevance of TEL in other more general fields is discussed as a potential contingency in the penultimate section of the paper. A theoretical framework for TEL is presented in the next section.

\section{THEORY OF EXPERT LEADERSHIP (TEL)}

The theory of expert leadership (TEL) can be represented by the following simple framework where $f(. .$.$) is a function and expert leadership depends on three kinds of 'inputs':$

\section{$\mathbf{E L}=\mathbf{f}(\mathbf{I K}, \mathbf{I E}, \mathbf{L C})$}

Expert leadership (EL) can be thought of as a function of: inherent knowledge (IK) which is acquired through technical knowledge of the core-business activity, attained through education and practice, combined with high ability in the core-business activity; second, industry experience (IE) which equates to time and practice in the core-business industry; finally, leadership capabilities (LC) which includes management and leadership experience and training, acquired during a leader's earlier career, and his or her innate characteristics. See Figure 1.

TEL makes the testable prediction that organizational performance will be positively correlated with leaders' inherent knowledge, and also their industry experience and 
leadership capabilities. Central to TEL is that each of these components is tied to the organization's core business. The core business is defined here as the primary or underlying activity; it is that which is considered to be the most important or central endeavor in an organization, and it generates the most attention and income. Furthermore, the core workers are identified in TEL. Core workers are classified in this paper as those employees most relied upon to undertake core business functions in order to maintain and also grow the organization; the principal, or core, employees may be the practicing lawyers in a law firm, surgeons in a hospital, the top designers in a fashion house, and so on.

Figure 1.

\section{Theory of Expert Leadership (TEL)}



$$
\text { EL }=\mathbf{f}(\text { IK, IE, LC) }
$$

As suggested above, the emphasis in TEL is on the core business being a primary factor that determines the leadership candidates. Similarly, the extent to which an individual 
has inherent knowledge about the core business should largely determine the leader. The main components in the TEL model are further developed in the next sections.

\section{Inherent knowledge}

Inherent knowledge, which is the principal factor, is internal or behavioral; it is acquired through technical education and practice, and is combined with high ability in the core-business activity. Inherent knowledge might also be described as a deep understanding that aids intuitive decision-making, akin to wisdom (Tichy \& Bennis 2007); it combines explicit and tacit knowledge (Nonaka and Takeuchi 1995). A unique feature of this paper and theory is the suggestion that organizational performance is improved when a leader has high or outstanding ability in the core business activity as compared with a candidate who is mediocre or low ability. In universities, for example, it is possible for an academic to drop out of research early in his or her career to become a full-time administrator. However, as mentioned above, these kinds of leaders were shown not to be beneficial to the performance of research universities; instead, the evidence suggests that the better the scholar as president, the better the future performance of the university (Goodall, 2009a,b).

Inherent knowledge means that a leader has expertise combined with ability in the underlying activity, which, as I suggest, is beneficial to future performance. This challenges a recent emphasis on management skills and CEO charisma (see Khurana, 2002). An extreme example of a sector that has gone over to manager-CEOs and away from technical experts is that of healthcare. In the past, qualified doctors ran hospitals. In the United States today only $4 \%$ of hospitals are led by medically trained doctors, most are instead professional managers (Gunderman \& Kanter, 2009) $)^{2}$.

\footnotetext{
${ }^{2}$ Healthcare spending in the US is substantial, at approximately $20 \%$ GDP (OECD).
} 
The importance of expertise to leaders in relation to employee creativity has been long established in the psychology literature. As discussed above, a leader's technical skill has been shown to be the best predictor of creativity and innovation (Andrews \& Farris, 1967; Barnowe, 1975; Mouly \& Sankaran. 1999; Mumford, 2000a,b; Mumford et al., 2002; Tierney, Farmer, \& Graen, 1999). The concept of inherent knowledge outlined in TEL is also allied to Salas and colleagues' 'expertise-based intuition' (Salas, Rosen \& DiazGranados 2010) which brings together the work on intuition and decision-making (e.g. Tversky \& Kahneman, 1981; Burke \& Miller, 1999; Lowenstein, 2000; Gigerenzer, 2007) with the literature on expertise (Ericsson, Charness, Feltovich \& Hoffman, 2006 ${ }^{3}$. Expertise is acquired through a combination of domain-specific knowledge and experience (Chase \& Simon, 1973; de Groot, 1978). Salas et al. argue that it is intuition informed by expertise that leads to effective intuitive decision making. Referencing Baylor (2001) and Hogarth (2001), Salas et al. define expertise-based intuition as the intuitions that occur when the decision maker has a deep and rich knowledge base from extensive experience within a domain (Salas et al. 2010, p. 944). Performance is attained through mechanisms of expert decision making derived from domain-knowledge, experience and practice (Ericsson, Krampe, \& TeschRomer, 1993; Salas \& Klein, 2001; Salas et al. 2010).

TEL extends these arguments. It suggests that the most important decision-maker the executive head -- should not only have domain knowledge and experience, he or she should be among the best experts in the domain that represents the organization's core business. For example, in an advertising agency it would be expected that the CEO should be among the most creative in the firm, with an outstanding track record.

\section{Testable proposition about inherent knowledge:}

\footnotetext{
${ }^{3}$ For a review of the literature see: Ericsson, Charness, Feltovich \& Hoffman (2006), and for a sociological perspective see Collins and Evans (2007).
} 
- For optimal performance in an organization, the ability of a leader in the core business activity should be equal to or not less than that of the best core workers.

- Organizations will perform less well if leaders are primarily generalists (e.g. professional managers).

\section{Industry experience}

The second component in the TEL model that contributes to expert leadership is industry experience, which can be expressed as time spent in or knowledge of the corebusiness industry or sector. This links, once again, with the literature on intuition and expertise; experts, it is argued, with extensive domain experience and practice have greater intuitive knowledge and make more effective decisions (Klein 1993, 2003; Dane and Pratt, 2007) which results in enhanced performance (Ericsson, Krampe, \& Tesch-Romer, 1993).

Industry experience is also related to the research on CEO origin, that attempts to identify a link between firm performance, among other outcomes, and whether a CEO has been hired from outside a firm or sector, or promoted from within (see Kesner \& Dalton, 1994; Shen \& Cannella, 2002; Wiersema, 1995; Zajac, 1990; Karaevli, 2007; Zhang \& Rajagopalan, 2004; Zhang \& Rajagopalan, 2010). Outsider CEO hires have risen since the early 1990s (Lucier, Schuyt \& Handa, 2003); nevertheless, the findings are ambiguous (Karaevli, 2007). In general terms, the evidence reveals that insider and outsider CEOs bring different perspectives that may prove beneficial under different conditions; dependent upon, for example, pre or post-succession firm performance, during periods of environmental munificence or turbulence, the level of strategic change that is introduced, and so on (Harris \& Helfat, 1997; Karaevli, 2007; Zhang \& Rajagopalan, 2010). Other variables are examined in the CEO origin literature (level of insiderness and outsiderness, age, education, top team demographics and turnover); however, none appear to examine CEO ability in the core 
business activity. Returning to the hospital example, it might be argued that manager-CEOs have plenty of knowledge about healthcare administration, finance and health policy because they may have worked their whole lives in the sector or hospital ${ }^{4}$. However, according to TEL, professional managers are classed as peripheral workers because the core business in hospitals is the practice of medicine; thus the core workers are doctors ${ }^{5}$. Arguably, leaders can learn a great deal by being exposed to a variety of experiences and practices, which may be why fewer CEOs spend their careers in a single organization (Frydman, 2007).

In the field of Formula 1 racing, Goodall and Progrebna (2012) show that former drivers go on to make the best F1 team leaders; this relationship is strengthened the more driver-years put in by the head.

Testable proposition about industry experience:

- Leaders who have spent most of their career in one sector (with a particular emphasis on the period prior to becoming a head), but not in one organization, will, typically, outperform those who have not.

\section{Leadership capabilities}

The third constituent in TEL, and arguably the most self-evident, focuses on the individual leader's capabilities: in particular, their management and leadership skills and also their innate characteristics. A leader may have acquired management skills through training and education, or they may have been learned from experience through promotion in their career. As might be presumed, inherent knowledge is not a proxy for management and

\footnotetext{
${ }^{4}$ As mentioned above, the most outstanding hospitals in the US identified by US News and World Report (USNWR) 'Best Hospital' are more likely to be led by CEOs who are MDs instead of professional managers (Goodall 2011b). Leaders of the USNWR 'Honor Roll' hospitals (those that perform the best in the highest number of medical specialties) are more likely to have been MDs who were also outstanding scholars.

${ }^{5}$ Arguably, other health workers might be classed as core workers also, such as nurses. Here, I view nurses as support personnel. Put simply, core workers are those without whom an organization ceases to be classified.
} 
leadership skills; irrespective of other factors, leaders must have adequate management knowledge and experience commensurate with the position. Leaders should be selected based on management skills as well as technical expertise (Mumford, 2000b).

At a firm level, good management practices are strongly associated with organizational performance and survival rates (Bloom \& Van Reenen, 2007; Bloom, Genakos, Martin \& Sadun, 2010). There has been much discussion amongst scholars and practitioners about the kind of skills that a successful leader should have. Leadership training is pervasive; it has become common for organizations of all types to invest in leadership courses for their junior and senior employees (Noe, Hollenbeck, Gerhart \& Wright, 1997; McCall, 1998; London \& Mone, 1999; Day, 2000). A recent survey of 750 American companies revealed that almost $\$ 11$ billion was spent on leadership programs in 2010 (O’Leonard, 2011). ${ }^{6}$

Central to TEL is the notion that leaders should primarily be specialists not generalists -- with firm-specific experience and core-business knowledge and ability. Recent evidence suggests that CEOs in the top US public companies have fewer technical qualifications (educational backgrounds in science, engineering or law) than their predecessors' decades earlier. In today's America, top executives are more likely to have a business degree (Murphy \& Zabojnik, 2006; Frydman, 2007). Gosling and Mintzberg (2004) suggest that up to $60 \%$ of MBA students from the most prestigious US schools go into consulting and investment banking where the highest salaries can be found. Frydman (2007) examines the career paths of the three highest-paid executives from 1936 to 2003 (total of 708 managers) in the top fifty US public corporations (in the year 1960). She documents three different but related patterns: the rise in the number of business degrees held by executives, starting in the 1970s, and the decline of technical degrees (science, engineering and law), that fell

\footnotetext{
${ }^{6}$ Thanks to Ganna Pogrebna for this point.
} 
dramatically in the 1990s. Second, she finds that executive mobility has increased over time, and most common among those with business degrees; finally, Frydman (2007) follows the rise in executive pay, from the late 1970s with the highest compensation growth taking place during the 1980s and 1990s. She shows that CEO salaries grew faster than other executives, and the most highly-paid executives were, once again, more likely to hold a business degree. It might be argued, therefore, that the upswing in generalist CEOs is correlated with greater mobility across firms by top executives, and a concomitant rise in CEO pay.

The decline of the US automobile industry, and the attendant dominance of Japan and Germany, has been linked to the above-mentioned shift away from employing technically trained executives towards generalist managers (Rother, 2010; Locke \& Spender, 2011). Liker, Fruin, \& Adler (1999) argued that US auto manufacturers failed to reproduce Toyota's production methods because US managers were too distant from the shop floor, caused by both their hierarchical corporate structures and the adversarial relationship between managers, employees and trade unions. This contrasts with Silicon Valley, where technical degrees are likely still to be more prevalent ${ }^{7}$.

Undoubtedly, leaders require substantial experience and/or training in management and leadership. However, many management courses are generic in their approach. Expert leaders require appropriate management training - ideally, training programs that are sectorspecific. It is unlikely to be efficient for organizations to send their best technicians, creatives, and scientists on lengthy courses that lack specificity ${ }^{8}$. It might be argued that this is not a good use of expert's time, and it is unlikely to encourage these individuals into management positions. Tailored MBAs have become more common (e.g. MBAs in

\footnotetext{
7 "The best engineers want to work with the best engineers," said Peter Fenton, a partner with a large venture capital firm (Benchmark Capital), engaged with a Silicon Valley based start-up (Tango). One of the cofounders of Tango has a PhD from Stanford in electrical engineering - BBC Business News, 9 May 2012 www.bbc.co.uk

${ }^{8}$ This was a complaint of Paul Nurse, Nobel Prize winner, when he became Director-General of Imperial Cancer Research Fund. He was sent on a course that he described as too long and too general.
} 
healthcare, industrial management, global energy ${ }^{9}$ ); nevertheless, many leadership and management programs tend not to be bespoke.

Experts frequently gain little or no status and benefits by completing management programs. Indeed, they may be judged critically by their peers. Consequently, appropriate incentives and rewards will be required to encourage experts to participate in training, and accept promotion into management positions. The promise of extra income may not be a suitable inducement for everyone (Amabile, 1993).

Since the financial crisis of 2008, there have been calls to professionalize management education. Khurana and Nohria (2008) suggested that some of the economic problems may have been averted if managers had followed a professional code. However, unlike law or medicine, management cannot easily be described as core business; it might be argued that it exists instead to support the core business. In disagreement with Khurana and Nohria (2008), might it instead be possible to ask whether the crisis stemmed in small part because of the over promotion of professional managers (Goodall 2011), particularly at the top of financial organizations.

Finally, individuals' innate characteristics will influence leadership ability and style. Leaders' personal characteristics are not the focus in the empirical work that supports TEL; however, they might include factors such as cognitive capability, self-control, resilience, and confidence, among others.

\section{Testable propositions about management and leadership:}

- Management programs that are closely tailored to core business requirements may be more likely to attract experts, and contribute to strategic requirements and

\footnotetext{
${ }^{9}$ Graduate Management Admission Council.
} 
organizational performance. The right programs may also promote less of an 'us and them' culture between specialists and managers.

- Take-up by experts will be higher if management and leadership training is designed to fit the needs of experts rather than generalists in terms of time, specificity and pitch (the language and concepts used should not be alien, i.e. the overuse of management jargon), and appropriate rewards and incentives should be used to motivate participation and promotion.

\section{HOW MIGHT EXPERT LEADERS POSITIVELY INFLUENCE ORGANIZATIONAL PERFORMANCE?}

In the paper so far, it has been suggested that expert leaders will have inherent knowledge about the core business, and high ability in the core activity; they should also have had substantial industry involvement, and, finally, management and leadership experience. This section focuses on how expert leaders might affect organizational performance; what are the transmission mechanisms? Five possible processes are discussed below, which are, again, linked to testable propositions. They are summarized in Figure 2.

\section{Knowledge-based strategy}

To become a successful expert, whether in architecture, retail or advertising, an individual will usually focus intensely on their subject and sector for a number of years, thereby amassing a deep knowledge base. This is often referred to in the literature as domain knowledge; that which has been acquired through education, training, and experience within a particular context. TEL proposes that a knowledge-based strategy 
will be more likely when a leader continues to align his or her strategic choices with those prioritized throughout their career as practicing experts and specialists. Aligning a leader's own career preferences and priorities with the requirements of the core business will, it is argued here, shape organizational strategy and decision-making. An example can be found in Barker and Mueller (2002), who show that research and development (R\&D) spending is significantly increased at firms where CEOs have advanced sciencerelated degrees, whereas, no effect was found from advanced training in business or law (Barker \& Mueller, 2002; see also Narayanan 2001). A knowledge-based strategy is that which combines a leader's inherent knowledge of the core business with the strategic direction of their organization (see Figure 3).

Figure 2

Leadership Framework

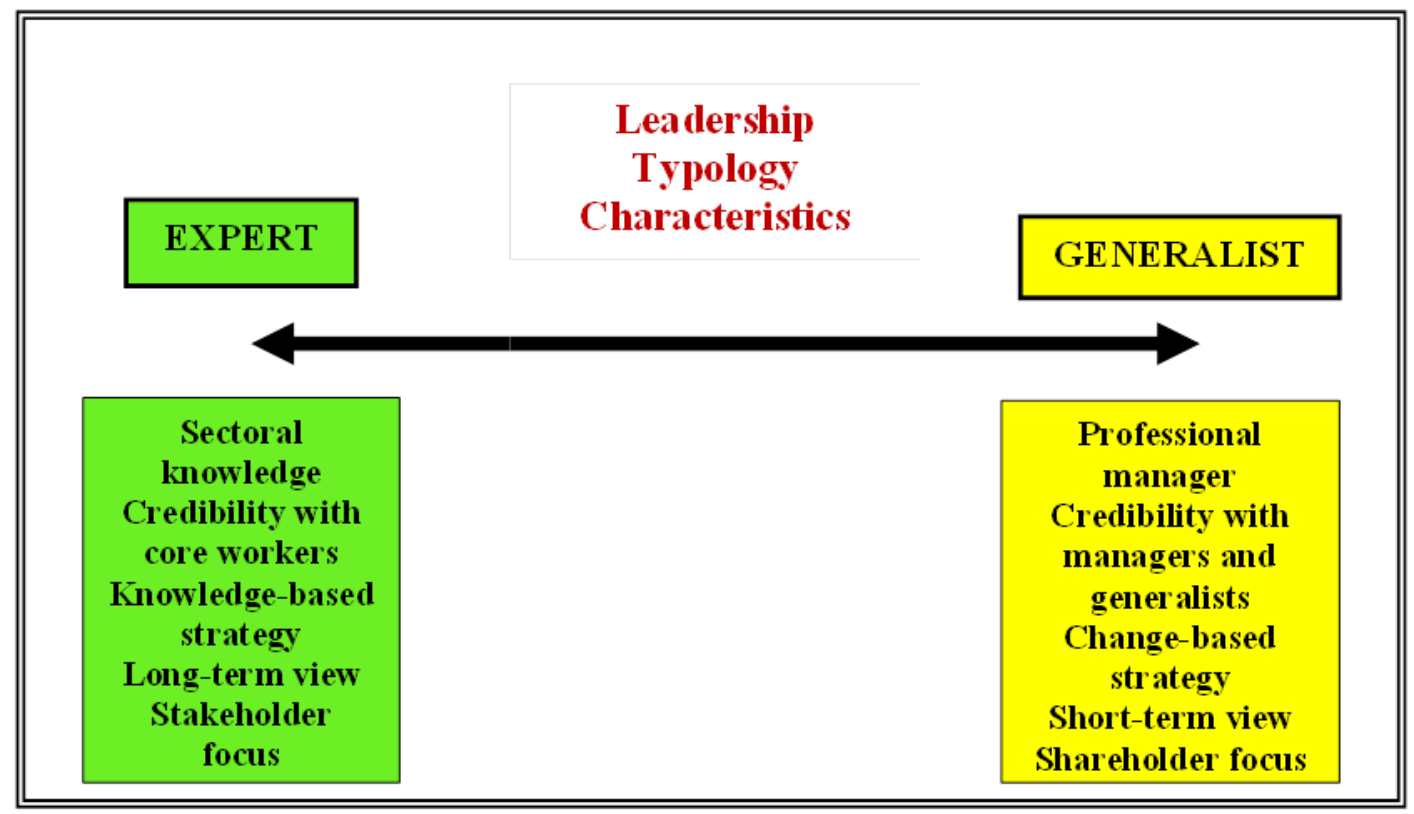

Goodall \& Edger 2011

This proposition connects with Hambrick \& Mason’s (1984) Upper Echelons (UE) theory (see Carpenter, Geletkanycz, \& Sanders, 2004 for a review). UE theory argues that top managers make strategic choices that are reflections of their own values and 
cognitions. Members of the top management team will be influenced in their decisionmaking by individual and group demographic factors (such as age, education, functional track, top management team heterogeneity, among others). UE theory focuses on the top management team (TMT) demographics, whereas TEL concentrates on CEO characteristics. The attention paid to the leader here is not to doubt the importance of the TMT in management and often strategy; however, in most organizations it is usual for heads to appoint their own TMT. We may expect, therefore, that it will be the CEOs preferences, derived from his or her demographic characteristics, that apply when the TMT are selected. Westphal \& Zajac (1995) document this pattern between CEOs and board directors; they show that when CEOs are dominant on boards, directors are more likely to share their demographic characteristics, and, similarly, when board members hold greater power, newly appointed directors will look similar to others on the board (Westphal \& Zajac, 1995).

Figure 3.

\section{Knowledge-based strategy}

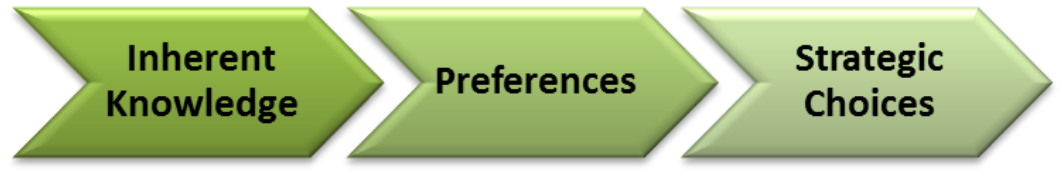

\section{Testable propositions about knowledge-based strategy:}

- Expert leaders are better at identifying strategic opportunities and challenges.

- Organizations led by leaders who have inherent knowledge in a particular area are more likely to yield greater innovation.

- Companies led by experts will invest more in $R \& D$. 
- Mergers \& acquisitions are likely to be more successful if the senior leadership in the dominant company has inherent knowledge in the area of the acquired or merged companies.

\section{Expert leaders as standard bearers}

How successful might a technology company or a school want to become? The arguments behind this proposition suggest that if a firm wants to be among the best in its field, then the board should hire a leader who is already one of the best in that same field. What effect might this have on performance?

TEL incorporates two key arguments: first, that it is the leader's responsibility to establish the quality threshold in an organization. If, therefore, an outstanding expert is hired, the bar is automatically raised. For example, when an exceptional chef owns a restaurant one might expect the standard to be high. A top chef will have focused intensely on all areas of food, with attention to detail and the setting of high personal standards. These standards may then be applied to the presentation of food, the restaurant environment, customer service, and so on. The owner-chef may not be directly acquainted with service management systems, but he or she might hire someone who can apply the same high standards.

It may also be easier for a leader to be an effective quality enforcer if he or she has first met the standard that is to be imposed (i.e. the standard bearer should first bear the standard). As shown in the literature, leaders need technical expertise to effectively evaluate the ideas of creative people, and provide appropriate feedback (Mumford et al., 2000; Basadur, Runco, \& Vega, 2000).

Second, many CEOs and HR directors will likely agree that hiring the best people is central to the success of any organization. Indeed, this might be viewed as somewhat obvious. Homophily in hiring and promotion happens when recruiters seek to 'reproduce 
themselves in their own image' (Kanter, 1977). That people select others who are like themselves is a form of assortative matching (Becker, 1973). The idea of 'self-replication' exists in a number of fields, particularly in biology, computer science and sociology. Management scholars have also looked at issues of demographic similarity between CEOs and boards (e.g. Westphal \& Zajac, 1995). Homophily, or self-selection, can lead to negative outcomes (i.e. discrimination), but it can also be a positive force. TEL suggests that an outstanding expert may be more likely to recognize other similar talent, and be willing to hire someone who is more able than they are. For example, in a school setting, the undergraduate backgrounds of principals' (school heads) are found to correlate with the academic undergraduate backgrounds of the teachers a head hires. Principals who attended more selective universities are more likely to hire teachers who have stronger academic backgrounds, which were shown to produce better student outcomes (Baker \& Cooper, 2005).

It has been suggested that humans find it hard to hire others who are better than themselves ${ }^{10}$. Sometimes, negative self-feelings can be traced directly to, and are antecedents of, processes of social comparison. Job satisfaction and happiness have been shown to be related to how the self compares with similar others (Stiles \& Kaplan, 2004, Clark \& Oswald, 1996; Luttmer, 2005, Card, Mas, Moretti \& Saez, 2010).

An important additional consideration is to establish what the appropriate level of expert knowledge should be in any given situation. For example, a laboratory that is undertaking research at the highest level may benefit directly from having a Nobel Prize winner at the helm. In this setting, the values, standards, and abilities of the leader and core

\footnotetext{
${ }^{10}$ This is captured in a statement attributed to André Weil, a French mathematician from the mid-20th Century, in his 'Weil's Law of university hiring': 'First rate people hire other first rate people. Second rate people hire third rate people. Third rate people hire fifth rate people.' Likewise, the American writer Leo Rosten is cited as having said, 'First-rate people hire first-rate people; second-rate people hire third-rate people.' In interviews with university presidents (Goodall 2009a), a number of heads commented on the need to put the most outstanding scholars on hiring panels to ensure that the best academics are hired.
} 
workers will be comparable. In contrast, a lab that is testing relatively simple constructs or technologies is less likely to benefit from being led by a scientist at the top of the field. TEL advocates that the level of inherent knowledge held by a head must be commensurate with that of the most important core workers, to facilitate communication, guidance and influence. Rosen (1982) and Lazear (2012) show that leaders are more likely to be drawn from among the most able individuals; furthermore, in a competitive labor market, the most able leaders naturally sort to the best firms. This pattern is found in Bridgewater, Kahn \& Goodall (2011) among football managers; those who played in the top divisions were more likely to manage a top division team, whereas those managers who formerly played in third or fourth divisions were more likely to manage teams in the lower leagues.

\section{Testable propositions of standard bearers:}

- An expert leader should be as skilled in the core business activity as the top $10 \%$ core workers in the organization.

- A leader who has inherent knowledge in the core business activity will demand higher quality from the core workers.

- The product or service that is the core business output can be expected to be of a higher standard if the head is an expert leader.

- An expert leader will hire core workers who are more talented; this will happen because expert leaders are more likely to put their best experts on all hiring panels.

- Expert leaders can more fully evaluate the performance of other core business workers.

- Board members who are on CEO hiring panels should also be expert leaders (a third to half panel members). 


\section{The credibility effect.}

Central to TEL is the notion that expert leaders command more respect because of their proven track record in the core business activity. The idea that credibility legitimizes leaders' authority is well documented in the literature (Bass, 1985; Bennis \& Nanus, 1985; Kouzes \& Posner, 2003). This approach focuses on the social interactions between leaders and their followers. TEL suggests that expert leaders are viewed as credible because they have 'walked-the-walk' to a high standard. It also signals that a head understands the culture and value system, incentives and priorities of those being led. Although credibility can be acquired because of inherent knowledge, arguably, in the long run, it must be maintained through good performance.

Hiring an outstanding expert may also signal credibility to a wider audience. For example, an organization's board may choose to hire a noted expert or specialist to send out a signal about strategic priorities to employees, and also to external stakeholders such as shareholders, customers, suppliers, the media, and donors.

\section{Testable propositions about credibility:}

- Expert leaders will be viewed as more credible by core workers, which will extend their influence.

- An expert leader can be hired as CEO to publicly signal organizational priorities, or to quell shareholder disquiet following a period of turmoil.

\section{Creating the right conditions for core workers.}

Expert leaders might be described as being the first among equals because they originated from the core workers. Having been 'one of them', expert leaders may be more 
likely to understand the culture and value system of core workers, and also their incentives and motivations.

In recent years there have been claims of over bureaucratization and managerialism in organizations, witnessed through intensified auditing, excessive controls and the overuse of accounting practices when measuring performance (Locke, 1996; Johnson \& Bröms, 2000; Khurana, 2002; Power, 2007). In the US and UK in particular, it has become less common to select managers from among core-business experts (Johnson \& Bröms, 2000).

TEL argues that expert leaders are more likely to create the right conditions for core workers, compared with leaders who are non-experts -- defined either as individuals who ceased working in the core business activity early in their careers, or professional managers. Work environments are known to be important to employees' creativity (Shalley, 1991, 1995), and to their creative performance (Amabile, Conti, Coon, Lazenby, \& Herron, 1996; Oldham \& Cummings, 1996). One of the most reported conditions found to enhance worker creativity is autonomy or having a sense of control on the job, either in terms of how work is done or how time is allocated. Creativity is viewed as being on a continuum (Shalley, 1991); correspondingly, the most creative individuals require the most autonomy. Creativity was found to be higher in scientists and R\&D researchers when they had freedom at work, received encouragement and had adequate resources (Andrews \& Farris, 1967; Hatcher, Ross, \& Collins, 1989; Amabile \& Gryskiewicz, 1987). Supportive supervisors also contribute to employees' creativity (Amabile \& Gryskiewicz, 1987; West \& Farr, 1989; Oldham \& Cummings, 1996). In contrast, conditions that have been found to inhibit creativity include, working in an overly controlled environment governed by rigid procedures, low levels of individual autonomy, the use of surveillance measures, reduced resources, and supervision that was viewed as critical and excessively monitoring (Amabile \& Gryskiewicz, 1987; West \& Farr, 1989). 
The role of leaders in promoting creativity has also received attention. Leaders can support and encourage creative individuals, but, more importantly, they need to ensure that the right work environment is created, with appropriate human resource practices in place (Drazin, Glynn, \& Kazanjian, 1999; Mumford, 2000a,b; Mumford et al., 2002; Oldham \& Cummings, 1996; Shalley, Gilson \& Blum, 2000; Tierney, et al., 1999; Tierney, 2008). These are summarised in Mumford et al. (2002): leaders with technical expertise can support creative employees through effective communication, appraisal, and mentoring. When the work environment complements the creative requirements of the job, individuals report higher job satisfaction and lower intentions to quit (Shalley et al., 2000).

TEL takes this idea a little further by arguing that the kind of leaders most likely to create the right conditions for their employees will be those who have similar abilities and creativity as their core employees. This may enable heads to challenge, empathise with and fully comprehend the needs of their most creative people.

Work environments that are found to be managed by supervisors who are supportive and not overly controlling foster creativity (Oldham \& Cummings, 1996). Expert leaders understand the conditions that are required because, as suggested above, they have direct knowledge of the field; thus, they will likely trust their employees with greater autonomy. In

contrast, to compensate for their lack of core business knowledge, a non-expert or a professional manager may be more likely to use managerial processes that they (as managers) have learned through training, and also from their own experience of being supervised by other managers.

\section{Testable propositions about the work environment:}

- Expert leaders are more likely to create a work environment that is conducive to high productivity in core workers. 
- Human resource procedures under expert leaders are likely to be less rigid and controlling, allow for greater autonomy, and use fewer surveillance measures.

- The more managers and administrators there are in an organization, the more administrative processes there are likely to be. This may hurt innovation, adaptability, responsiveness and the bottom line. Expert leaders are more likely to streamline managerial processes to ensure there is not an imbalance in the number of managers compared to experts.

\section{Intrinsic motivation and the long view}

The education and on-the-job training required to become an expert, specialist or professional is substantial -- up to eight years in the case of an architect, longer to become a competent surgeon. Experts are more often self-motivated -- driven by intrinsically motivated curiosity -- rather than by purely extrinsic factors, such as money (Amabile, 1993, 1995). Intrinsic motivation is defined as 'the drive to do something for the sheer enjoyment, interest, and personal challenge of the task itself (rather than solely for some external goal)', (Hennessey \& Amabile, 2010, p. 581). Individuals who enter into long qualification periods are intrinsically motivated. Extrinsic factors such as money are viewed as less important, and in the case of creativity, somewhat detrimental (Amabile et al., 1996). Creative and professional people are also more likely to have their personal identity enmeshed with their work, and, therefore, professional success and recognition is a powerful motivator (Harrel \& Stahl 1981, Rostan 1998). Also, creative people tend to value more appraisal by the profession compared than the employers (Goulder, 1958; Bradway, 1971; Organ \& Green, 1981).

TEL suggests that leaders who are intrinsically motivated by the core business -- who are experts in the core business activity and have worked intensively in the field for much of 
their life -- may be more likely to adopt strategic choices that follow a long view with regards income and profit generation. In contrast, it is the adoption of a short view -- or shorttermism (Laverty, 1996; Palley, 1997; Marginson \& Mcaulay, 2008) -- that is often linked by scholars (Nesbitt, 2009; Dallas, 2011) and commentators (e.g. The Economist, Nov 13, 2009) to the financial crisis of 2008. CEO short-termism, demonstrated for example in the length of CEO decision horizon, is linked with a preference for investments with faster paybacks, to the detriment of long-term value creation (Antia, Pantzalis \& Park, 2010). As reported above, generalist CEOs have increased in number over the last two decades (Frydman, 2007); TEL proposes that generalist CEOs are more likely to follow a strategy of short-termism than expert leaders.

Technology and R\&D investment might be viewed as being central to a long term perspective; in particular, if technology is seen as a core asset and allowed a reasonable return on investment. This issue may be raised when companies go public: board members and investors may want a quick turnaround on investments. It is suggested here that expert leaders (and those on boards with inherent knowledge) may be more likely to invest in, and nurture, new technologies. Barker and Mueller (2002) found that CEOs with technical degrees, and who were younger and have investments in firm stock, are more likely to invest in R\&D. The author's also show that CEO tenure is linked to R\&D spending -- the longer the tenure, the greater the investment (Barker \& Mueller, 2002). In a similar vein, Mumford et al. (2002) highlight the inherent conflict between innovation and organization. Innovation must normally follow a degree of failure; creating new technologies and products is expensive and risky. An expert leader may be more likely to understand this process. 


\section{Testable propositions about the long view:}

- Leaders who are intrinsically motivated are more likely to adopt a long term strategy for their organizations when compared to leaders who are extrinsically motivated.

- CEOs, board members and investors who have inherent knowledge are more likely to take risks and invest in technology and $R \& D$.

- Expert leaders may be less likely to impose a culture of constant change management.

\section{THEORY BOUNDARIES}

The limitations of theories should be determined empirically. The theory of expert leaders outlined in this paper grew from research into university leaders (Goodall 2006). A pattern was observed that has now been replicated in several studies focusing on different settings (research universities, soccer, basketball, hospitals and Formula 1 racing). With each new piece of research comes a little more understanding about the possible contingencies of the theory; however, I am some way from identifying fully its boundaries. Nevertheless, this penultimate part of the paper will focus first on making an estimate about how much organizational performance might be explained by expert leadership; second, it will suggest potential boundaries of TEL, and, finally, the possible weaknesses of expert leaders will be considered.

\section{How much of the performance can be explained by expert leaders?}

Recently there has been ambiguity about who leaders are (Grint 2005). This is exemplified in the multiplicity of leadership programs targeted at almost anyone. In TEL leaders are not viewed as being everywhere, as these programs might imply, they are somewhere specific - located at the top of the executive tree (e.g. CEO, president, managing 
director). They are hired by, and ultimately responsible to, a board of directors. Central to TEL is the notion that leaders matter to the performance of organizations. Exactly how much expert leaders might matter is discussed here.

This paper rejects the view of those who seek to politicize the study of leaders by suggesting that the dichotomy of leader/follower is an ideological construct (e.g. Gemmill \& Oakley, 1992; Alvesson \& Sveningsson, 2003; Alvesson \& Spicer, 2012); instead leadership is viewed here as an empirical reality. Leaders will vary in their abilities and suitability to different posts (Rosen, 1982; Bridgewater, et.al., 2011), and, given the costs of hiring and firing them, it is my belief that this is an important research topic.

The notion that leaders are necessarily charismatic and deserving of extraordinary conditions is also rejected here (summarized in Khurana 2007). It is anticipated that TEL incorporates an objective view of leaders, and the assessment of their performance. This is a challenging task because of the difficulties in linking leaders causally to their organizations' performance. It is not possible in a giant experiment to randomly assign leaders to institutions. Therefore, other statistical methods need to be applied to try to get closer to causal inference (see Antonakis, Bendahan, Jacquart \& Lalive, 2010 ${ }^{11}$ ).

Many variables beyond a leader's characteristics will impact on organizations -- the economic climate, board members, state regulation, among others. Similarly, the powers vested in leaders will differ widely across sectors and firms. For example, in the global sport of soccer, some managers control the flow in and out of players while some have little say. Arguably, the quality of one's players is key to any team's success (Bridgewater et al. 2011).

How much performance might we expect leaders to explain? The research on expert leaders summarized above (i.e. Goodall, 2006, 2009a,b, 2012; Goodall, Kahn \& Oswald, 2011, Goodall \& Progrebna, 2012) includes both simple cross-section analyses with a small

\footnotetext{
${ }^{11}$ Antonakis, Bendahan, Jacquart \& Lalive (2010) published an insightful summary of the issues associated with causal inference and leadership research. They also make recommendations.
} 
number of control variables and longitudinal multiple-regression equations. These results suggest that the size of the expert-leader effect on organizational performance may be between $15-20$ per cent. This would imply that approximately one fifth of organizational performance can be explained by a leader's inherent knowledge of the core business, and by his or her ability in the core activity.

\section{The boundaries of TEL}

As suggested earlier, boundary conditions should be established empirically. Thus far, evidence in support of expert leaders - outlined in the second section of the paper mostly derives from knowledge-intensive and high-skill settings (e.g. research groups, universities, hospitals, basketball teams and Formula 1 racing). These situations have been studied partly because measurement of productivity is relatively simple; for example, it is possible to apportion research outputs to individuals, groups and institutions. Similarly, hospitals are publicly ranked according to quality measures; basketball games are competitively played and won; All-Star payers are selected, and so on.

Does TEL apply in other types of settings? Might it be possible for a high street retailer to become a successful banker? ${ }^{12}$ Could a social worker take over running a sports center? Could a professional manager who is not a journalist become a newspaper editor? When a TV production company specializing on sports programs buys a production company concentrating on period drama, will the latter's performance wane? What if there are multiple and varied outputs? For example, leadership in an organization consisting only of professionals, who all share a discipline, might be simpler than in settings with multiple

\footnotetext{
${ }^{12}$ Not in the case of CEO, Andy Hornby the former head of Halifax Bank of Scotland (HBOS), one of Europe's largest banks. HBOS was rescued from failure by the UK government in October 2008, and forced into an emergency takeover by Lloyds TSB, another major UK bank. Notably few years in Hornby's career were spent in banking. He began his professional life with a cement maker (Blue Circle Industries) in 1993. Between 1996 and 1999 he worked at Asda, a British retail grocery business owned by Wal-Mart. In 1999 he joined the Halifax Bank prior to its merger with the Bank of Scotland, and became COO in 2005, and CEO of the merged HBOS in 2006. The bank failed 2 years later.
} 
(potentially competing) types of professionals (i.e. in a development company with developers, architects, engineers, project managers, etc.). Might professional rivalries undermine expert leadership? This is an issue often discussed in universities, because of fears that disciplinary favoritism might distort organizational priorities (e.g. the London School of Economics never hire's internal faculty members to become Director for this reason).

Experts may have a narrow perspective of the world. Being overly focused might stifle original thinking or lead to 'groupthink' (Janis 1983). It might be argued (and often is) that an expert surgeon is less able to make judgments about other fields, like acute care or preventative medicine, and, therefore, a generalist or lay person may be better placed to weigh up competing arguments. However, a general manager may also have a contracted perspective if, for example, he or she has come from a finance background or marketing. This issue may also arise in performance management and assessment, especially in the provision of complex services, such as healthcare or education. The priorities of a professional or expert might differ from those of a manager.

A possible reason why professional managers have assumed greater powers may be because of the importance of modern management practices to successful performance (Bloom \& Van Reenen 2007). Experts and professionals may have been slower to adopt these applications. Also, an industry may have declined in prominence due to its outdated norms and operations, and may require an injection of new blood from outside (Spender, 1989).

This paper contends, first, that it is the person who holds the most power who should be the expert leader, and, second, that this rule could apply across many sectors, albeit is to be determined empirically. While there will always be examples of outsiders who bring innovative practices to organizations, TEL predicts that in usual circumstances, performance will improve or be maintained when the head of an organization in any situation has core 
business knowledge and expertise. However, the level of inherent knowledge held by those in organizations with an unclear core business (multiple and varied outputs) may be less significant.

\section{Testable proposition about the boundaries of TEL:}

- TEL is not only applicable in knowledge-intensive, high-skill or professional settings. It applies to the organizational leader across many sectors.

- Where there are multiple organizational outputs (where the core business is less clear), there may also be greater variation in the inherent knowledge of the leader.

\section{The potential weaknesses of expert leaders}

This paper argues that being a successful manager alone is not a sufficient condition for effective leadership; but, correspondingly, experts must also be excellent managers. There are important reasons why those who have become experts in their field must invest heavily in their own development: specialists have focused intensely on their subject, often to the detriment of other areas of personal development. Being intrinsically motivated, to the extent that experts are, will likely require shutting out the world for some years lest it distracts from the goal in hand.

Intrinsic motivation combined with a lot of self-motivation may leave specialists too self-focused; they may lack the ability to put themselves in others shoes. It has been suggested that leaders need empathy if they are to be successful (Maccoby, 2000; Kelletta, Humphrey \& Sleeth, 2006). Hubris might be a weakness of experts (Edger 2012). An individual who has succeeded in one area might become overly confident about their abilities in other areas. A successful surgeon praised for his or her technical skills, more adored because of saving lives, might overemphasize their talent. Arguably, some among the 
world's CEOs might be considered over-confident or arrogant, yet qualities that are often highlighted as being important to leaders are integrity and empathy, and both may require humility. There is a tendency for successful people to attribute their ascent to their own brilliant talent -- as predicted by social psychology's attribution theory (Heider 1958). Success, arguably, comes also from luck, networking and providence.

\section{Testable proposition about the potential weaknesses of expert leaders:}

- People who are outstanding experts and professionals may overemphasize their abilities in other areas. In addition to good management and leadership skills, the best-performing expert leaders may be those who show humility (a capability to listen to others) instead of hubris (expressed as over self-confidence).

\section{CONCLUSION}

According to the arguments laid out in this paper, organizations, from government departments to banks and technology firms, need to ask the question: does our leader really understand this business? In choosing a leader, how competent should that person be in the core activity of his or her organization? Should he or she be someone with a deep knowledge of the industry or sector, or instead a talented manager with generic skills but little or no detailed expertise in the specialist business of that organization (or somewhere in between, and if so where)? Perhaps surprisingly, this is not a question that has been systematically addressed in the management literature.

The theory of expert leaders (TEL) presented here builds upon, and attempts to blend, a range of conceptual literatures and empirical evidence. A number of testable predictions have been described. The framework sketched here suggests that organizations will perform 
more effectively when led by individuals who have deep expertise in the core business of their organization. Being a capable general manager, it has been argued, is not sufficient. Expert leaders are those with (1) inherent knowledge, defined as technical knowledge of the core-business activity, acquired through education, combined with high ability in the corebusiness activity; (2) industry experience, which equates to time and practice in the corebusiness industry; and (3) leadership capabilities, that include management and leadership skills and experience, that combine with his or her innate characteristics.

This paper and theory is thus implicitly critical of the empirically-documented rise of the professional manager and generalist CEO. Whilst acknowledging possible limitations, the paper argues that expert leaders can be expected to improve organizational performance through knowledge-based strategy, by acting as a standard bearer, by creating an intrinsically attractive environment for core workers, and, finally, by adopting the long view. 


\section{REFERENCES}

Alvesson, M. \& Sveningsson, S. 2003. Good visions, bad micro-management and ugly ambiguity: Contradictions of (non) leadership in knowledge-intensive organization. Organization Studies, 24(6): 961-988.

Alvesson, M. \& Spicer, A. 2012. Critical leadership studies: The case for critical performativity. Human Relations, 65(3) 367-390.

Amabile, T. M. 1993. Motivational synergy: Toward new conceptualizations of intrinsic and extrinsic motivation in the workplace. Human Resource Management, 3 (3): 185201.

Amabile, T. M. 1995. Attributions of creativity: What are the consequences? Creativity Research, 8 (4): 423-426.

Amabile, T. M., \& Gryskiewicz, N. D. 1989. The creative environment scales: work environment inventory. Creativity Research Journal, 2, 231-253.

Amabile, T. M., Conti, R., Coon, H., Lazenby, J., \& Herron, M. 1996. Assessing work environment for creativity. Academy of Management Journal, 39, 1118-1154.

Andrews, F. M., \& Farris, G. F. 1967. Supervisory practices and innovation in scientific teams. Personnel Psychology, 20, 497-515.

Antia, M., Pantzalis, C. \& Park, J.C. 2010. CEO decision horizon and firm performance: An empirical investigation. Journal of Corporate Finance, 16 (3): 288-301.

Antonakis, J., Bendahan, S., Jacquart, P. \& Lalive, R. 2010. On making causal claims: A review and recommendations. Leadership Quarterly, 21 (6): 1086-1120.

Baker, B.D., Cooper, B.S. 2005. Do principals with stronger academic backgrounds hire better teachers? Policy implications for high poverty schools. Educational Administration Quarterly, 41 (3) 449-479. 
Barnowe, J. T. 1975. Leadership and performance outcomes in research organizations. Organizational Behavior and Human Performance, 14, 264-280.

Barker, V. L. \& Mueller, G. C. 2002. CEO characteristics and firm R\&D spending. Management Science, 48 (6): 782-801

Basadur, M., Runco, M. A., \& Vega, L. A. 2000. Understanding how creative thinking skills, attitudes, and behaviors work together: a causal process model. Journal of Creative Behavior, 34, 77-100.

Bass, B. M. 1985. Leadership and performance beyond expectation. New York: Free Press.

Becker, G. S. 1973. A theory of marriage: Part I. Journal of Political Economy, 81 (4): 81346.

Bennis, W. G. \& Nannis, B. 1985. Leaders. New York: Harper \& Row.

Bertrand, M. 2009. CEOs. Annual Review of Economics, 1:1.1-1.29

Bertrand, M., \& Schoar, A. 2003. Managing with style: The effect of managers on firm policies. Quarterly Journal of Economics, 118 (4) 1169-1208.

Bloom, N., \& Van Reenen, J. 2007. Measuring and explaining management practices across firms and countries. Quarterly Journal of Economics, 122 (4) 1351-1408.

Bloom, N., Genakos, C., Martin, R. \& Sadun, R. 2010. Modern management: good for the environment or just hot air? Economic Journal, 120 (544): 551-572.

Bishop, M. The Economist, Nov 13th 2009. Now for the long term: It's time for businesses to think about the future again.

Bradway, M. K. 1971. Understanding the role orientations of scientists and engineers. Personnel Journal, 35, 449-454.

Bridgewater, S, Kahn, L.M. \& Goodall, A.H. 2011. Substitution between managers and subordinates: Evidence from British football. Labour Economics, 18 (3): 275-286. 
Burke, L. A., \& Miller, M. K. 1999. Taking the mystery out of intuitive decision making. Academy of Management Executive, 13: 91-99.

Card, D, Mas, A, Moretti, E, Saez, E. 2010 Inequality at Work: The effect of peer salaries on job satisfaction. NBER Working Paper No. 16396.

Cannella, A.A., \& Lubatkin, M. 1993. Succession as a sociopolitical process: Internal impediments to outsider selection. Academy of Management Journal, 36: 763-793.

Carpenter, M.A., Geletkanycz, M.A. \& Sanders, W.G. 2004. Upper echelons research revisited: Antecedents, elements, and consequences of top management team composition. Journal of Management, 30 (6): 749-778.

Chase, W. G., \& Simon, H. A. 1973. Perception in chess. Cognitive Psychology, 4: 55-81.

Clark, A. E. \& Oswald, A. J. 1996. Satisfaction and comparison income. Journal of Public Economics, 61: 359-381.

Collins, H., \& Evans, R. 2007. Rethinking Expertise. Chicago: University of Chicago Press.

Dane, E., \& Pratt, M. G. 2007. Exploring intuition and its role in managerial decision making. Academy of Management Review, 32: 33-64.

Dane, E. 2010. Reconsidering the trade-off between expertise and flexibility: A cognitive entrenchment perspective. Academy of Management Review, 35 (4): 579-603.

Dane, E. 2011. Paying attention to mindfulness and its effects on task performance in the workplace. Journal of Management, 37 (4): 997-1018.

Day, D.V. 2000. Leadership development: A review in context. Leadership Quarterly, 11 (4): 581-613.

Dallas, L., 2011. Short-termism, the financial crisis and corporate governance. San Diego Legal Studies Paper No. 11-052. Available at SSRN: http://ssrn.com/abstract=1794190. 
Drazin, R., Glynn, M. A., \& Kazanjian, R. K. 1999. Multilevel theorizing about creativity in organizations: a sense making perspective. Academy of Management Review, 24, $286-329$.

Edger, C. 2012. Effective multi-unit leadership: Local leadership in multi-site situations. UK: Gower.

Ericsson, K. A., Krampe, R. T., \& Tesch-Romer, C. 1993. The role of deliberate practice in the acquisition of expert performance. Psychological Review, 100: 363-406.

Ericsson, K. A., Charness, N., Feltovich, P. J. \& Hoffman R. R. (Eds.), 2006. The Cambridge handbook of expertise and expert performance. New York: Cambridge University Press.

Finkelstein, S., Hambrick, D.C. 1990. Top-management-team tenure and organizational outcomes: The moderating role of managerial discretion. Administrative Science Quarterly, 35: 484-503.

Frydman, C. 2007. Rising through the ranks: The evolution of the market for corporate executives, 1936-2003. Journal of Economic History, 66 (2): 516-517.

Gemmill, G. \& Oakley, J. 1992. Leadership: An alienating social myth. Human Relations 45(2): 113-129.

Goodall, A.H. 2006. Should top universities be led by top researchers, and are they? Journal of Documentation, 62, 388-411.

Goodall, A.H. 2007. Does it take an expert to lead experts? The case of universities. PhD Thesis, Warwick Business School, University of Warwick.

Goodall, A.H. 2009a. Highly cited leaders and the performance of research universities. Research Policy, 38 (7): 1079-1092.

Goodall, A.H. 2009b. Socrates in the boardroom: Why research universities should be led by top scholars, Princeton and Oxford: Princeton University Press. 
Goodall, A.H. 2011. Physician-leaders and hospital performance: Is there an association? Social Science and Medicine, 73 (4): 535-539.

Goodall, A.H., Kahn, L.M. \& Oswald, A.J. 2011. Why do leaders matter? A study of expert knowledge in a superstar setting. Journal of Economic Behavior \& Organization, 77: $265-284$.

Goodall, A.H. \& Pogrebna, G. 2012. Expert leaders in a fast moving setting, IZA Working paper, IZA Institute for the Study of Labor, Bonn, Germany.

Gosling, J. \& Mintzberg, H. 2004. The education of practicing managers, Sloan Management Review, 45 (4): 19-22.

Goulder, A. W. 1958. Cosmopolitans and locals: toward an analysis of latent social roles. Administrative Science Quarterly, 2, 444-480.

de Groot, A. 1978. Thought and choice in chess (2nd ed.). The Hague, the Netherlands:. Mouton De Gruyter.

Gunderman, R., \& Kanter, S. L. 2009. Educating physicians to lead hospitals. Academic Medicine, 84:1348-1351.

Grint, K 2005. Leadership: Limits and Possibilities. London: Palgrave.

Hambrick, D.C., \& Mason, P. 1984. Upper echelons: The organization as a reflection of its top managers. Academy of Management Review, 9: 193-206.

Harrel, A. M., \& Stahl, M. J. 1981. A behavioral decision theory approach for measuring McClelland's trichotomy of needs. Journal of Applied Psychology, 66, 242-247.

Hatcher, L., Ross, T.L. \& Collins, B. 1987. Prosocial behavior, job complexity, and suggestion contribution under gainsharing plans. Journal of Applied Behavioral Science, 25(3): 231-248.

Heider, F. 1958. The psychology of interpersonal relations. New York: John Wiley \& Sons. 
Hennessey, B.A. \& Amabile, T.M. 2010. Creativity. Annual Review of Psychology, 61: 569-98.

Hogarth, R. M. 2001. Educating intuition. Chicago: University of Chicago Press.

Janis, I. 1972. Victims of groupthink. Boston: Houghton Mifflin.

Johnson, H. T. \& Broms. A. 2000. Profit beyond measure: Extraordinary results through attention to work and people. New York: The Free Press.

Kanter, R. 1977. Men and women of the corporation. New York: Basic Books,

Karaevli, A. 2007. Performance Consequences of New CEO “Outsiderness": Moderating Effects of Pre- and Post-Succession Contexts. Strategic Management Journal, 28: 681-706.

Kelletta, J. B., Humphrey R. H. \& Sleeth, R. G. 2006. Empathy and the emergence of task and relations leaders. The Leadership Quarterly, 17 (2): 146-162.

Kesner, I.F., Dalton, D.R.. 1994. Top management turnover and CEO succession: An investigation of the effects of turnover on performance. Journal of Management Studies, 31: 701-713.

Khurana, R. 2002. Searching for a corporate savior: The irrational quest for charismatic CEOs. Princeton and Oxford: Princeton University Press.

Khurana, R. 2007. From higher aims to hired hands: The social transformation of American business schools and the unfulfilled promise of management as a profession. Princeton and Oxford: Princeton University Press.

Khurana, R. \& Nohria, N. 2008. It's time to make management a true profession, Harvard Business Review, 86 (10): 70-77.

Klein, G. 1993. A recognition primed decision (RPD) model of rapid decision making. In G. Klein, J. Orasanu, R. Calderwood, and C. E. Zsambok (Eds.), Decision making in action, 138-147. New Jersey: Ablex. 
Klein, G. 2003. The power of intuition. New York: Doubleday.

Kotter, J. 1990. What leaders do. Harvard Business Review, May-June: 103-111.

Kouzes, J. M. \& Posner, B. Z. 2003. Credibility: How leaders gain and lose it, why people demand it. Jossey-Bass: USA.

Laverty, K.J. 1996. Economic "short-termism": The debate, the unresolved issues, and the implications for management practice and research. Academy of Management Review, 21(3): 825-860.

Lazear, E. P. 2012. Leadership: A personnel economics approach. Labour Economics, 19: 1 $92-101$

Liker, J., Fruin, M., Adler, P. S. (Eds.), 1999. Remade in America: Transplanting and transforming Japanese management systems. New York: Oxford University Press.

Locke, R.R. 1996. The collapse of the American management mystique. Oxford: Oxford University Press.

Locke, R.R \& Spender, J.C. 2011. Confronting managerialism: How the business elite and their schools threw our lives out of balance. London \& New York: Zed Books.

London, M. \& Mone, E.M. 1998. Continuous learning. In Ilgen, D. R. \& Pulakos, E. D. (Eds) The changing nature of performance: Implications for staffing, motivation and development, California: Jossey-Bass.

Lucier, C., Schuyt, R. \& Handa, J. 2003. CEO succession 2003: The 'perils' of good governance. McLean, VA: Booz Allen Hamilton.

Luttmer, E. F. P. 2005. Neighbors as negatives: Relative earnings and well-being, Quarterly Journal of Economics, 120 (3): 963-1002.

Maccoby. M. 2000. Narcissistic leaders, Harvard Business Review, 78 (1): 68-72.

Marginson, D. \& Mcaulay, L. 2008. Exploring the debate on short-termism: A theoretical and empirical analysis. Strategic Management Journal, 29 (3): 273-292. 
McAuley, J., Duberley, S., \& Cohen, L. 2000. The meaning professional give to management and strategy. Human Relations, 53, 87-116.

McCall, M.W. 1998. High flyers: Developing the next generation of leaders. Cambridge, MA: Harvard Business School Press.

Mouly, V. S., \& Sankaran, J. K. 1999. The '"permanent'” acting leader: insights from a dying Indian R\&D organization. Leadership Quarterly, 10, 637-652.

Mumford, M. D. 2000a. Managing creative people: strategies and tactics for innovation. Human Resource Management Review, 10, 1-29.

Mumford, M. D. 2000b. Managing creative people: strategy and tactics for innovation. Human Resource Management Review, 10, 313-351.

Mumford, M. D., Marks, M. A., Connelly, M. S., Zaccaro, S. J., \& Reiter-Palmon, R. 2000. Development of leadership skills: experience, timing, and growth. Leadership Quarterly, 11, 87-114.

Mumford, M.D., Scott, G.M., Gaddis, B., Strange, J.M., 2002. Leading creative people: Orchestrating expertise and relationships. Leadership Quarterly, 13 (6): 705-750.

Murphy, K.J. \& Zabojnik, J. 2006. Managerial capital and the market for CEOs. Working Paper, USC.

Narayanan, V. K. 2001. Managing technology and innovation for competitive advantage.

Englewood Cliffs, NJ: Prentice Hall Longman.

Nesbitt, J. 2009. The role of short-termism in financial market crises. Australian Accounting Review, 19: 4 314-318.

Noe, R., Hollenbeck, J., Gerhart, B. \& Wright, P. 1997. Human resource management: Gaining a competitive advantage with OLC card. McGraw-Hill Higher Education, Columbus, $\mathrm{OH}$. 
Nonaka, I. \& Takeuchi, H. 1995. The knowledge-creating company. NY: Oxford University Press.

Oldham, G. R., \& Cummings, A. 1996. Employee creativity: personal and contextual factors at work. Academy of Management Journal, 39, 607-634.

O'Leonard, K. 2011. Talent acquisition factbook 2011: Benchmarks and trends of spending, staffing and key talent metrics. Report produced by Bersin \& Associates, Oakland, California.

Organ, D. W., \& Green, C. N. 1981. The effects of formalization on professional involvement: a compensatory process approach. Administrative Science Quarterly, $26,237-252$.

Rosen, S. 1982. Authority, control and the distribution of earnings. Bell Journal of Economics, 13, 311-323.

Rostan, S. M. 1998. A study of young artists: the emergence of artistic and creative identity. Journal of Creative Behavior, 32, 278-301.

Rother, M. 2010. Toyota Kata: Managing people for improvement, addictiveness and superior results. New York: McGraw-Hill.

Salas, E., Rosen M.A. \& DiazGranados, D. 2010. Expertise-based intuition and decision making in organizations. Journal of Management, 36: 941.

Shalley, C. E. 1991. Effects of productivity goals, creativity goals, and personal discretion on individual creativity. Journal of Applied Psychology, 76: 179-185.

Shalley, C. E. 1995. Effects of coaction, expected evaluation, and goal setting on creativity and productivity. Academy of Management Journal, 38, 483-503.

Shalley, C.E., Gilson, L.L. \& Blum, T.C. 2000. Matching creativity requirements and the work environment: Effects on satisfaction and intensions to leave. Academy of Management Journal, 43 (2): 215-223. 
Shen, W., Cannella, A.A., 2002. Revisiting the performance consequences of CEO succession: The impact of successor type, post-succession senior executive turnover, and departing CEO tenure. Academy of Management Journal 45: 717-733.

Stiles, B. L., \& Kaplan, H. B. 2004. Adverse social comparison processes and negative selffeelings: A test of alternative models, social behavior and personality. An International Journal, 32 (1): 31-44.

Spender, J.C. 1989. Industry recipes: An enquiry into the nature and sources of managerial judgement. Oxford: Basil Blackwell.

Thamin, H. J., \& Gemmill, L. R. 1974. Influence styles of project managers: some project performance correlates. Academy of Management Journal, 17, 216-223.

Tierney, P., Farmer, S. M., \& Graen, G. B. 1999. An examination of leadership and employee creativity: the relevance of traits and relationships. Personnel Psychology, 52, 591620.

Tierney, P. 2008. Leadership and employee creativity. In J. Zhou and C. E. Shalley (Eds.), Handbook of organizational creativity, pp. 95-124, NY: Lawrence Erlbaum.

Tichy, N.M. \& Bennis, W.G. 2007. Making judgement calls. Harvard Business Review, October, 94-102.

Tversky, A., \& Kahneman, D. 1981. Judgment under uncertainty: Heuristics and biases. Science, 185: 1124-1131.

Palley, T. I. 1997. Managerial turnover and the theory of short-termism. Journal of Economic Behavior \& Organization, 32 (4): 547-557.

Pfeffer, J. 1977. The ambiguity of leadership. Academy of Management Review, 2, 104112.

Power, M.K. 2007. Organized uncertainty: Designing a world of risk management. Oxford: Oxford University Press. 
West, M. A. \& Farr, J. L. 1989. Innovation at work: psychological perspectives. Social Behaviour, 4: 15-30.

Westphal, J. D. \& Zajac, E. J. 1995. Who shall govern? CEO/board power, demographic similarity, and new director selection. Administrative Science Quarterly, 40, 6083.

Wiersema, M.F. 1995. Executive succession as an antecedent to corporate restructuring. Human Resource Management, 34: 185-202.

Zajac, E.J. 1990. CEO selection, succession, compensation, and firm performance: A theoretical integration and empirical evidence. Strategic Management Journal, 11: $217-230$.

Zhang, Y. \& Rajagopalan, N. 2003. Explaining new CEO origin: Firm versus industry Antecedents. Academy of Management Journal, 46: 327-338.

Zhang Y, Rajagopalan N. 2004. When the known devil is better than an unknown God: An empirical study of the antecedents and consequences of relay CEO successions. Academy of Management Journal, 47: 483-500. 